\title{
Effect of vitamins on ovarian and reproductive tract development and reproductive performance in prepubertal gilts
}

\author{
C. de Alba ${ }^{1}$, A. J. Zięcik ${ }^{2}$, A. Fuentes ${ }^{3}$, C. García ${ }^{4}$, J. Riopérez \\ B. Jana ${ }^{1}$, J. M. Flores ${ }^{4}$ and S. Rillo ${ }^{2}$
}

'KUBUS S.A., Calle s/n. Poligono Industrial Európolis

280-230 Las Rozas, Madrid, Spain

'Institute of Animal Reproduction and Food Reseurch. Polish Academy of Sciences Tuwima 10, 10-746 Olsztyn, Poland

${ }^{3}$ Instituto de Investigaciónes Zootécnicas, Av. Universidad

Via El Limón, Maracay 2101, Venezuela

${ }^{4}$ Facultad de Veterinaria de Madrid UCM

Madrid, Spain

${ }^{5}$ Instituto de Nutrición y Bromatologia, Faculdad de Farmacia, Ciudad Universitaria $s / n$

280-40 Madrid, Spain

(Received 22 February 2000; accepted 15 July 2000)

\begin{abstract}
Experiments involving 118 prepubertal gilts (150-180 days old) were conducted to evaluate the effect of vitamin administration on reproductive tract development and ovarian responsiveness to exogenous gonadotropins.

In Experiment 1 prepubertal Duroc gilts were assigned to two groups and injected or not with vitamins and Se and 14 days later given $600 \mathrm{IU}$ PMSG and $200 \mathrm{IU}$ hCG. Gilts were slaughtered on day 7 post oestrus detection. Vitamins and Se increased the length $(P<0.05)$ but not the weight of the uterus and ovaries. The number of corpora lutea decreased $(\mathrm{P}<0.001)$ but their size increased $(\mathrm{P}<0.01)$ in the vitamin- and Se-treated group when compared to controls.

In Experiment 2 gilts were injected with vitamins and Se as described in Experiment 1 ten days before PMSG/hCG and the treated gilts were injected again with vitamins and Se four days prior to the expected onset of the second oestrus. Gilts that did not express signs of the second oestrus after treatment were slaughtered on day 27 post onset of the first oestrus. Gilts given vitamins and $\mathrm{Se}$ had heavier and longer uteri $(\mathrm{P}<0.01)$ and a lower number of corpora albicans $(\mathrm{P}<0.01)$ in the previous
\end{abstract}

2 Corresponding author 
oestrous cycle. The relatively high number of corpora albicans found both in control $(26.5 \pm 3.1)$ and vitamin-treated (34.1 \pm 2.3 ) gilts after PMSG/hCG injection in Experiment 2 indicates an inconsistent response of prepubertal gilts to gonadotropins.

We concluded that vitamin- and Se-flushing led to the formation of lower in number but larger in size corpora lutea after ovulation probably duc to the progression of a smaller number of follicles to the ovulatory stage. Vitamins and Se increased the development of the uterus but did not influence the number of piglets at farrowing.

KEY WORDS: vitamins, reproductive tract, puberty, gilts

\section{INTRODUCTION}

Inducing oestrus in gilts before their introduction into a breeding herd can be a very uscful tool for improving pig production efficiency. Although methods of oestrus synchronization of mature gilts and post-weaned sows give relatively good results, the induction of fertile oestrus in prepubertal gilts still needs improvement. Application of different doses and combinations of pregnant mare's gonadotropin (PMSG) and human chorionic gonadotropin (hCG) provides different, sometimes controversial results (Britt et al., 1989; Karalus et al., 1990; Ziçcik et al., 1996; Martín Rillo et al., 1997). Until now there is no commonly accepted method for inducing oestrus in prepubertal gilts that ensures reproducible results of fertility during the first induced oestrus. Even the most predictable and effective method of using boar contact is not consistent since the pubertal response of gilts to a male does not occur in a fixed time period (Hughes et al., 1990). According to the above authors variations observed between studies in female response to boar contact reflect confounding factors such as genotype, climate, housing cnvironment, nutritional status and age of gilts. Also, a high percentage of gilts do not maintain cyclic ovarian activity (Karalus et al., 1990; Martín Rillo et al., 1997).

Variations in vitamin and mineral supplementation can significantly influence reproductive processes (Hidiroglou et al., 1992; Coffey and Britt, 1993). The roles of vitamins and minerals in pig reproduction generally and attainment of puberty, in particular, have received very little attention (Hughes, 1982). It does seem probable that severe restriction of many vitamins and minerals, including vitamin $\mathrm{A}$ (Hughes, 1934), vitamin $\mathrm{B}_{12}$ (Johnsen et al., 1952) and manganese (Plumlee et al., 1956), may delay sexual development. According to Okere and Hacker (1995) the administration of vitamins and minerals before and during gestation enhances the reproductive capacity of gilts by stimulating follicular development in ovaries. Our recent study showed that vitamin/mincral supplementation of the basal diet in prepuberal gilts can increase the number of lutcinizing hormone receptors in ovaries (Zięcik et al., 2000). This suggests that vitamin or mineral treatment (flushing) can raise the responsiveness of prepubertal gilts to exogenous gonadotropins. 
The aim of this study was to determine the effect of vitamin flushing on ovaries and reproductive tract development, oestrus induction and further reproductive performance in prepubertal gilts.

\section{MATERIAL AND METHODS}

\section{Experiment 1}

The objective of Experiment 1 was to examine the effect of vitamin and selenium $(\mathrm{Sc})$ injection on induction of ocstrus in prepubertal gilts by treatment with a combination of PMSG and hCG. The experiment was conducted on one swine farm in Bajadoz (Spain). Fifty Duroc, gilts $150-160$ days of age and 85 to $95 \mathrm{~kg}$ body weight (BW), with no behavioural signs of oestrus (presumed to be prepubertal) were kept in finishing facilitics ( 10 gilts per pen) and fed with a basal diet $(2.87 \mathrm{Kcal} / \mathrm{kg}$; and (in \%): crude protein 17.6; fat 4.4: fibre 4.7; methionine 0.25 ; methionine+cystine 0.55 ; lysine 0.88 ; thrconine 0.62 ), randomly assigned to two groups of equal number and injected or not (control) with 900000 IU Vitamin (Vit.) A +300000 IU Vit. $D_{3}+300 \mathrm{mg}$ Vit. $\mathrm{E}+0.25 \mathrm{mg}$ of Sc in $4 \mathrm{ml}$ of propriety vchicle (VIGANTOL-E, Bayer-3 ml + SEFEROL, Fort Dodge-1 ml). Fourteen days later all gilts were moved from finishing facilitics and injected with $600 \mathrm{IU}$ PMSG (Folligon) and $200 \mathrm{IU}$ hCG (Chorulon), both gonadotropins donated by Intervet-Spain, in $2 \mathrm{ml}$ of salinc. Treatments were given by i.m. injection into the neck behind an ear. From since 110 days of age the gilts were provided ad libitum with water and a commercial diet containing 16\% crude protein. From day 3 until day 6 after PMSG/hCG injection all of the gilts were tested once a day by standing in heat test in the presence of a mature boar. Ten gilts from cach group exhibiting oestrus (randomly chosen) were slaughtered on day 7 post oestrus detection, and the weight and length of the uterus were recorded. One ovary was fixed in Bouin's fluid, embedded in paraffin wax and serially sectioncd. Evcry 50 th section $(6 \mu \mathrm{m})$ was stained with hematoxylin-cosin for histological examination. The rest of the gilts became pregnant, delivered and the number of piglets and their weights were recorded.

\section{Experiment 2}

Sixty-eight Duroc gilts (150-160 days of age and 85 to $95 \mathrm{~kg} \mathrm{BW})$ were randomly assigned to two groups of equal number and were injected or not (control) with vitamins and $\mathrm{Se}$ as described in Experiment 1 at the same farm, 10 days before the first administration of 600 IU PMSG and 200 IU hCG for oestrus induction. Twenty-ninc control and thirty-one vitamin- and Se-treated gilts showed first oestrous behaviour in 4-5 days. 
The treated animals were injected again with vitamin and Se solutions 4 days prior to the expected day of onset of the second spontaneous oestrus (i.e. on days 17-18 after onset of the first PMSG/hCG induced standing oestrus), while control gilts received injections of vehicle. All gilts that showed spontaneous second standing oestrus were artificially inseminated twice using a two-phase method $(30 \mathrm{ml}$ of Synthetic Seminal Plasma; Predil MR-AŇ; KUBUS S.A., Spain, followed by a dose of semen). Gilts were then left until farrowing.

Scven control and eight vitamin-treated gilts that did not express signs of the second oestrus after treatment were slaughtered on day 27 post onset of the first ocstrus for reproductive tract examination.

\section{Data and statistical analysis}

All data were presented as mean \pm SEM and compared by analysis of variance (ANOVA) to establish the overall effect of treatment. In addition, comparisons of means were performed by Duncan's multiple range test or the Bonferroni test.

The effect of diameter of the corpus luteum on ovarian section was subjected to regression analysis. All calculations were performed using the statistical package GraphPad PRISM (GraphPad Software, San Diego, CA, USA).

\section{RESULTS}

\section{Experiment 1}

Treatment of gilts with vitamins and Se 14 days before gonadotropin injections did not affect the percentage of gilts in oestrus within day 4 and 5 . The percentage of gilts detected in heat on day 4 was 62.5 and 67.5 and on day 5, 72.5 and 80.0 percent in the control and treated groups, respectively.

Ovarian and utcrine responses of gilts slaughtered after PMSG/hCG treatment resulted in higher uterine length $(\mathrm{P}<0.05)$ and slight but not significant $(\mathrm{P}>0.05)$ increase in uterine weight. Vitamins and Se did not affect ovarian weight but decreased the number of corpora lutea by $32.4 \% \mathrm{t}(\mathrm{P}<0.001)$ when compared with controls (Table 1). Figure 1 shows a typical corpus luteum section of control (a) and vitamin- and Sc-treated (b) gilts. Developed corpora lutea were found in the ovaries of both groups of gilts. The number of corpora lutea (mean \pm SEM) per ovarian section was higher in controls $(11.32 \pm 0.47)$ than in vitamin- and Se-treated $(8.03 \pm 0.34 ; \mathrm{P}<0.01)$ animals, but the diameter of the corpora lutea was significantly lower in controls than in the treated group $(3.79 \pm 0.07$ vs $4.30 \pm 0.11 \mathrm{~mm}$; $\mathrm{P}<0.01$, respectively). Despite this there was a significant negative correlation between the diameter of corpora lutea and their number on ovarian sections 
TABLE 1

Ovarian and uterine response of control and vitamins + Se treated gilts and slaughtered 7 days after PMSG/hCG injection in Experiment 1

\begin{tabular}{ccccc}
\hline Goups & $\begin{array}{c}\text { Weight of ovary } \\
\mathrm{g}\end{array}$ & $\begin{array}{c}\text { Number of } \\
\text { corpora lutea }\end{array}$ & $\begin{array}{c}\text { Weight of } \\
\text { uterus, } \mathrm{g}\end{array}$ & $\begin{array}{c}\text { Length of uterine } \\
\text { horns, } \mathrm{cm}\end{array}$ \\
\hline Control & & & & \\
$\mathrm{n}=10$ & $9.3 \pm 0.8$ & $16.7 \pm 0.9$ & $276.5 \pm 17.0$ & $141.3 \pm 3.4$ \\
Vitamins + Se & $11.7 \pm 1.9$ & $11.3 \pm 1.9$ & $287.0 \pm 22.0$ & $189.1 \pm 11.2$ \\
$\mathrm{n}=10$ & & $\mathrm{P}<0.001$ & & $\mathrm{P}<0.01$ \\
\hline
\end{tabular}

$(y=5.18-0.117 x ; r=-0.63, P<0.01$; Figure 2$)$. No asynchronies between both ovaries and both uterine horn weights were observed with respect to the studied parameters.

\section{Experiment 2}

Treatment of gilts with vitamins and Se 10 days before stimulation of oestrus with PMSG/hCG also did not increase the percentage of gilts in oestrus within 5 days (84.7, control vs 92.9, vitamins and Se). Among 31 vitamin- and Se-treated and 29 control gilts, that were injected again with vitamins and Se or vehicle (control) 4 days before the expected onset of oestrus, $19(61.3 \%)$ treated and $12(41.4 \%)$
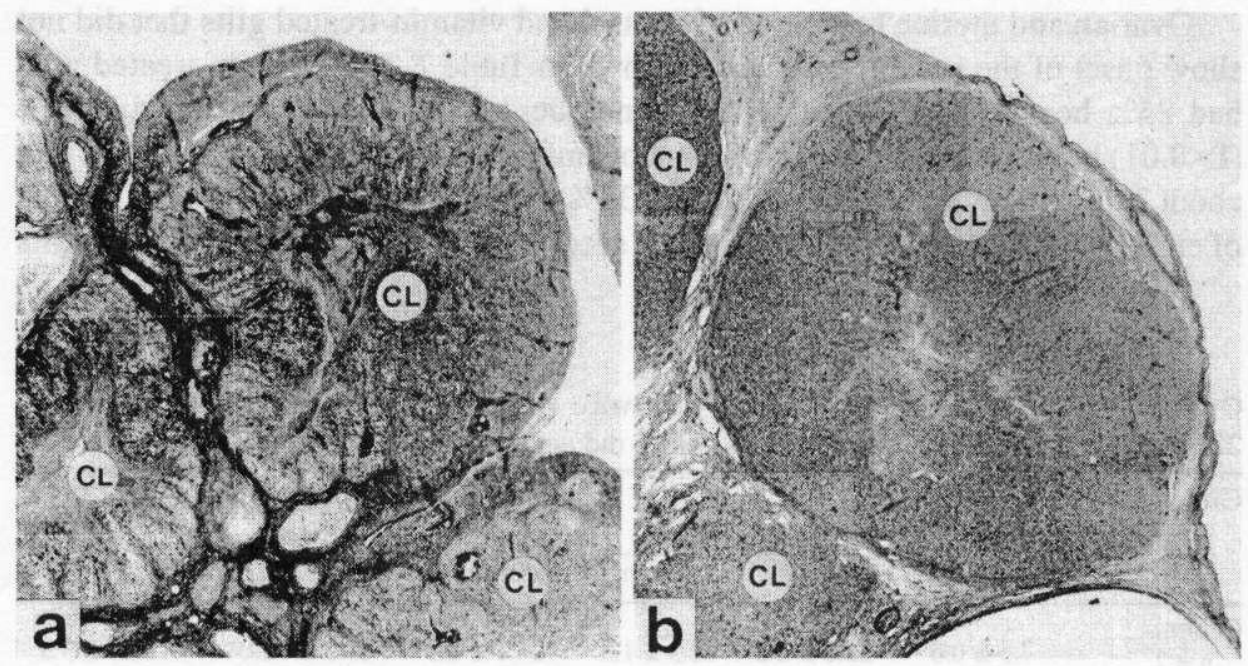

Figure 1. Corpus luteum section of control (a) and vitamins and Se treated gilts (b).

Magnification x 15. CL - corpus luteum 


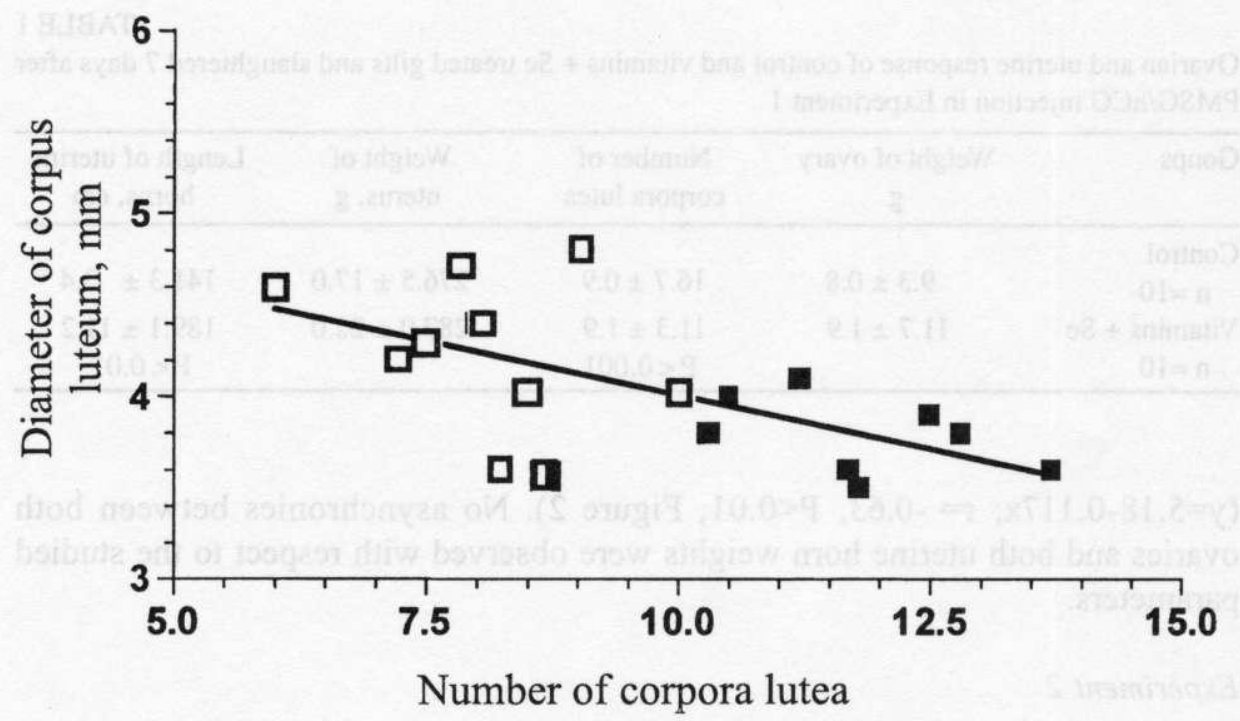

Figure 2. Correlation between diameter of corpus luteum and number of corpora lutea in ovarian section ( - vitamins treated gilts; $\square$ - control gilts)

control gilts showed oestrus behaviour $(\mathrm{P}>0.05)$. All of those gilts were inseminated during the second oestrus, i.e. 21-23 days after the onset of the first PMSG/ hCG-induced heat.

Ovarian and uterine responses of control and vitamin-treated gilts that did not show onset of the second oestrus are shown in Table 2 . The vitamin-treated gilts had $25 \%$ heavier ovaries and a higher number of follicles $>3 \mathrm{~mm}$ of diameter $(\mathrm{P}<0.01)$ but lower number of corpora albicans $(\mathrm{P}<0.01)$. Gilts given vitamins had about 2 times heavier uteri $(\mathrm{P}<0.01)$ and $33 \%$ longer uterine horns $(\mathrm{P}<0.01)$. None of eight control and three of eleven of the second time vitamin- and Se-treated gilts

TABLE 2

Ovarian and uterine responses of control and twice vitamins plus Se treated (10 prior and 21 22 days after PMSG/hCG injection) gilts, which did not show the onset of the second oestrus

\begin{tabular}{|c|c|c|c|c|c|c|}
\hline \multirow[t]{2}{*}{ Groups } & \multirow{2}{*}{$\begin{array}{c}\text { Weight of } \\
\text { ovaries } \\
\text { g }\end{array}$} & \multicolumn{2}{|c|}{$\begin{array}{l}\text { Total number of } \\
\text { surface follicles }\end{array}$} & \multirow{2}{*}{$\begin{array}{c}\text { Number of } \\
\text { corpora } \\
\text { albicans }\end{array}$} & \multirow{2}{*}{$\begin{array}{c}\text { Weight of } \\
\text { uterus } \\
\mathrm{g}\end{array}$} & \multirow{2}{*}{$\begin{array}{c}\text { Length of } \\
\text { uterine } \\
\mathrm{cm}\end{array}$} \\
\hline & & $<3 \mathrm{~mm}$ & $>3 \mathrm{~mm}$ & & & \\
\hline $\begin{array}{r}\text { Control } \\
n=7\end{array}$ & $7.5 \pm 0.6$ & $22.6 \pm 2.2$ & $12.3 \pm 1.3$ & $34.1 \pm 2.3$ & $63.5 \pm 12.0$ & $112.5 \pm 3.3$ \\
\hline $\begin{array}{l}\text { Vitamins }+\mathrm{Se} \\
\quad \mathrm{n}=8\end{array}$ & $10.9 \pm 0.6$ & $19.5 \pm 4.8$ & $\begin{array}{c}19.5 \pm 1.9 \\
P<0.01\end{array}$ & $\begin{array}{c}26.5 \pm 3.1 \\
P<0.01\end{array}$ & $\begin{array}{c}347.4 \pm 19.0 \\
P<0.01\end{array}$ & $\begin{array}{c}149.7 \pm 4.5 \\
P<0.01\end{array}$ \\
\hline
\end{tabular}


inseminated during the second oestrus returned to oestrus after the breeding period. The number of total piglets born at farrowing did not differ between groups and averaged $8.7 \pm 1.1(6-12)$ for controls, compared with $8.7 \pm 1.3(6-14)$ for the gilts injected twice with vitamins and Se; piglet birth weight did not differ either ( $1.14 \pm 0.08$ vs $1.15 \pm 0.13$, respectively).

\section{DISCUSSION}

Treatment of gilts in Experiments 1 and 2 with vitamins and Se did not increase the percentage of gilts in oestrus after gonadotropin stimulation. It is worth noticing, however, that the number of gilts showing ocstrus within 5 days after a single PMSG/hCG injection in this herd (Zięcik et al., 1996), was extraordinarily high when compared with the data of Britt et al. (1989), which found only $52 \%$ gilts in oestrus within 5 days after PG-600 (400 IU PMSG and $200 \mathrm{IU}$ hCG) administration. This can be cxplained by the fact that the Bajadoz herd has been selected for early puberty through many generations and that in our experiment a higher dose of PMSG (600 IU) was used.

One of the most interesting observations coming from the results of ovarian examination performed 7 days after PMSG/hCG-induced oestrus was the significant decrease in the number of corpora lutea in the vitamin- and Se-treated gilts, whereas the weight of ovaries was not changed or even slightly increased. This was caused by development of larger corpora lutea in the vitamin- and Se-treated animals, as shown in the histological sections. The weight of the corpus luteum is related, on the one hand, to follicle dimension at ovulation (Soede et al., 1998). On the other hand, the vitamin treatment probably caused development of smaller number of follicles to the ovulation stage from the group of recruited follicles. Whether the larger size of ovulatory follicles and the size of the corpora lutea were the reason for their compensatory faster growth, or if this was related to the direct influence of treatment remains to be explained. The lower ovulation rate in the animals treated with excess vitamins and Se could cause inhibition of follicle selection in the ovulatory population at the hypothalamus-pituitary (number of LH pulses) or/and ovarian level (inhibin, growth factors. estradiol, etc.).

The relatively high number of corpora albicans (ovulation rate) found both in control and vitamin-treated gilts in Experiment 2 indicates that in those animals $\mathrm{PMSG} / \mathrm{hCG}$ injection caused supcrovulation of follicles. This difference in ovulation rate between Experiments 1 and 2 confirms the inconsistent response of prepubertal gilts to gonadotropins in many recorded parameters. For example Karalus et al. (1990) reported occurrence of ocstrus in 45/46 prepubertal gilts (120-160 days old) after "classical" treatment with gonadotropins whereas Zięcik et al. (1996) found only full signs of oestrus in 3/36 similarly trcated. 165-day-old prepubertal 
gilts. The reasons for such differences can depend on differences in climate (light, temperature), breed, and access to a boar or some unidentified local environmental factors. The low percentage of gilts showing a second spontaneous oestrus is a common failure of oestrus induction in prepubertal gilts with PMSG/hCG also reportcd by Karalus et al. (1990), Zięcik et al. (1996) and De Alba et al. (1998). Regular cyclicity depends on hypothalamic-pituitary-ovarian axis development and the degree of its maturity, which can be affected by age and weight (Esbenshade ct al., 1982). Our recent study showed that vitamin and Se treatment is not a way to increase the percentage of gilts exhibiting follow up oestrus after PMSG/hCG induction of the first pubertal oestrus, but perhaps vitamin and mineral ,flushing" together with glucose supplementation can improve oestrus bchaviour (Fucntes et al., 1998). Further studies are needed before it is possible to decide whether vitamin supplementation will have any actual benefits for proven fertility of gilts, or better responses to gonadotropin treatment.

\section{CONCLUSIONS}

Vitamin and Se flushing led to the formation of lower in number but larger in size corpora lutea after ovulation probably due to the progression of a smaller number of follicles to the ovulatory stage. Vitamins and Se increased the development of the uterus but did not influence the number of piglets at farrowing. Additional studies will be required to determine whether vitamin and mineral supplementation can alter reproductive performance in prepubertal gilts.

\section{REFERENCES}

Britl J.H., Day B.N., Webel S.K., Brauer M.A., 1989. Induction of fertile cstrus in prepuberal gilts by treatment with a combination of pregnant mare's serum gonadotropin and human chorionic gonadotropin. J. Anim. Sci. 67, 1148-1153

Coffey M.T. Britt J.H.. 1993. Enhancement of sow reproductive performance by $\beta$-carotene or vitamin A. J. Anim. Sci. 71. 1198-1202

De Alba C., Fuentes A., Rioperez. J., Ziçcik A., García C., Martín Rillo S., 1998. Effect of vitamin and mineral flushing (Vit. A, D , E and Se) on the development of the genital tract. ovary activity and litter size in gilts. Proceeding of $15^{\text {th }}$ IPVS Congress, Birmingham (England ), p. 42

Esbenshade L.K., Paterson A.M., Cantley T.C., Day B.N., 1982. Changes in plasma hormone concentrations associated with the onset of puberty in the gilt. J. Anim. Sci. 54, 320-324

Fuentes A., Rioperez J., Cidoncha R., García J.A., De Alba C., Martín Rillo S., 1998. Administration of glucose and vitamin-mineral $\left(A, D_{3}, E\right.$ and $S e$ ) on the onset of heat in gilts induced with PMSG and hCG. Proceedings of $15^{\text {th }}$ IPVS Congress, Birmingham (England), p.76 
Hidiroglou N., Cave N., Atwal A.S., Farnworth E.R., McDowell LR., 1992. Comparative vitamin E requirements and metabolism in livestock. Ann. Rech. Vet. 23, 337-359

Hughes E.H., 1934. Some effects of vitamin A-deficient diets on reproduction in sows. Agr. Res. 49. 943-953

Hughes P.E.. 1982. Factors affecting the natural attainment of puberty in the gilt. In: D.J.A. Cole, G.R. Foxcroft (Editors). Control of Pig Reproduction. Butterworths, London, pp. 117-138

Hughes P.E., Pcarce G.P., Paterson A.M., 1990. Mechanisms mediating the stimulatory effects of the boar on gilt reproduction. J. Reprod. Fertil., Suppl. 40, 323-341

Johnsen H.H.K., Moustgaard J., Hojgaard-Otsen N., 1952. The significance of vilamin $B_{12}$ for the fertility of sows and gilts. Anim. Breed. Abstr. 23, 784

Karalus U., Downey B.R., Ainsworth L., 1990. Maintenance of ovulatory cycles and pregnancy in prepuberal gilts treated with PMSG and hCG. Anim. Reprod. Sci. 22, 235-241

Martín Rillo S., de Alba C., Pedrazuela R., García C.. Zięcik A., 1997. Effect of hormonal treatment with PMSG and hCG in the ovarian of prepuberal gils. $48^{\text {th }}$ Annual Meeting of the European Association for Animal Production, Vienna (Austria), p. 455

Okere C., Hacker R., 1995. Reproductive and endocrine responses of gestating gilts to selected micro-nutrient supplementation. J. Anim. Sci. 73. Suppl. 1. 251 (Abstr. 562)

Plumlee M.D., Thrasher D.M., Beeson W.W., Andrews F.N., Parker H.E., 1956. The effects of manganese deficiency upon the growth development and reproduction of swine. J. Anim. Sci. 15, 352-367

Socde N.M., Hazeleger W., Kemp B., 1998. Follicle size in pigs: prediction of oestrus and ovulation and effects on subsequent luteal and embryo development. Proceeding of $15^{\text {th }}$ IPVS Congress, Birmingham (England), p. 42

Zięcik A.J., Dybala J., Martin Rillo S., Kapelański W., Biegniewski S., De Alba Romero C., Gajewski Z., 1996. Induction of fertile estrus in prepuberal gilts and weaned sows. Reprod. Domest. Anim. 31, 469-472

Zięcik A.J., Kapelański W., Stępień A., Rioperez J., De Alba C., 2000. Ovarian and reproductive tract responses to vitamins and minerals supplementation in prepubertal gilts. J Anim. Feed Sci. $9,471-478$ 


\section{STRESZCZENIE}

\section{Wplyw witamin na rozwój jajników i układu rozrodezego oraz użytkowość rozrodezą niedojrzalych plciowo loszek}

Doświadczenia przeprowadzono na 118 niedojrzałych płciowo loszkach, w wieku ok. 180 dni, w celu zbadania wpływu dodatku witamin na rozwój układu rozrodczego oraz wrażliwość na egzogenne gonadotropiny. W doświadczeniu 1, niedojrzałe płciowo loszki rasy Duroc podzielono na dwie grupy, z których jedna otrzymała inickcję witamin z dodatkiem selenu (Se) na czternaście dni przed podaniem 600 IU PMSG i 200 IU hCG. Loszki ubito w 7 dniu po wykryciu rui. Witaminy i Se spowodowały wzrost długości rogów macicy $(\mathrm{P}<0,05)$, ale nie wpłynęły na ciężar macicy i jajników. Liczba ciałek zółtych obniżyła się $(\mathrm{P}<0,001)$, ale ich rozmiary zwiększyły się $(\mathrm{P}<0,01)$ w grupie otrzymującej witaminy i Se w porównaniu z grupą kontrolną. W doświadczeniu 2 loszki otrzymywały inickcje witamin i Se tak samo jak w doświadczeniu 1 na 10 dni przed podaniem $\mathrm{PMSG} / \mathrm{hCG}$, a następnie loszki te poddano powtórnic iniekcji witamin i Se w czwartym dniu przed wykryciem spodziewanej drugiej rui. Loszki, u których nie zaobserwowano objawów drugiej rui zostały ubite w 27 dniu po wystapieniu pierwszej rui. Loszki otrzymujące witaminy i Se miały cięższe i dłuższe macice $(\mathrm{P}<0.01)$ i mniejszą liczbę ciałek żółtych białawych $(\mathrm{P}<0,01)$ w poprzednim cyklu rujowym. Stosunkowo duża liczba ciałek białawych, stwicrdzona zarówno u zwierząt kontrolnych $(26,5 \pm 3,1)$ jak i otr7ymujących witaminy $(34,1 \pm 2,3)$ u loszek po iniekcji PMSG/hCG w doświadczeniu 2, wskazuje na zmienną reakcję niedojrzałych płciowo loszck na gonadotropiny.

Uzyskane wyniki pozwalają na wyciągnięcic wniosku, że witaminowo-selenowy ,flushing” spowodował tworzenie się mniejszej liczby, ale większych ciałek żółtych po owulacji, prawdopodobnie na skutek rozwoju mniejszcj liczby przedowulacyjnych pęcherzyków. Witaminy i Se przyspieszyły rozwój macicy, ale nie miały wpływu na liczbę urodzonych prosiąt. 